\title{
Examining the Intricacy of Character Formation among Kenyan Children: The Diminishing Role of Schools
}

\author{
W. Osabwa, J. Ogeno, and D. B. Nyanje
}

\section{ABSTRACT}

Kenya, like the rest of the world, is grappling with the problem of undesirable character among its citizens. Whereas the country's system of education identifies character formation as one of the aims of its education, the same is not reflected in the products of the system. This paper sought to reflect over the whole affair of character formation, with special focus on why schools have not been able to successfully achieve this important learning outcome. The paper, drawn from an earlier analytical study on pedagogies of character formation among Kenyan schools, exposed the underbelly of society in general, where the latter passed as a major impediment towards character formation efforts. Some influencers, among them showbiz celebrities and political icons, proved quite impressionistic to youngsters, hence drawing them into the vices they portrayed. Families, on the other hand, had not fully lived up to their primary duty of moulding children into righteous beings, and various reasons were advanced. However, schools, despite their infirmities, were established as the better option, owing to their relatively structured way of forming character among children. Whereas they were variously blamed for the mess in the society, they still remained the only reliable agent that the country relied on - given the professionalism within them, and the amount of time children spent there. It is for this reason that the paper advocated the strengthening of character formation programmes in schools, specifically, finding ways through which knowledge on and conviction for good character could best be communicated to learners.

Published Online: January 25, 2022

ISSN: $2736-4534$

DOI : 10.24018/ejedu.2022.3.1.225

\section{W. Osabwa*}

Educational Foundations Department, School of Education, Kenyatta University, Nairobi, Kenya.

(e-mail: wycliffe.ayieko@yahoo.com) J. Ogeno

Educational Foundations Department, School of Education, Kenyatta University, Nairobi, Kenya.

(e-mail: ogeno.jackton ${ }^{\circledR}$ ku.ac.ke)

D. B. Nyanje

Educational Foundations Department, School of Education, Kenyatta University, Nairobi, Kenya.

(e-mail: nyanjebatso ${ }^{\circledR}$ ku.ac.ke)

*Corresponding Author

Keywords: Character Formation, Schools, Society, Kenya

\section{INTRODUCTION}

"The creatures outside looked from pig to man, and from man to pig, and from pig to man again; but already it was impossible to say which was which." George Orwell, Animal Farm.

There is no contention over the significance of good character in any civilization. Granted, each member would wish that every individual around them behaved well. Accordingly, society has come to accept the objective nature of good character, the reason why various approaches have been instituted towards its formation.

Generally, the society has various institutions which interact to ensure harmony and productivity. Viewed as social structures, they are variedly classified into units such as the family, religion, government, the education sector, and the economy, among others (Parsons, 1951; Knapp, 1994). Whereas each is inclined to perform certain functions more than others, most of the units converge on the function of forming good character among the citizenry. The family, religion, government and education are notably critical. For instance, the family is considered the primary agent of socializing young ones into individuals of good standing (Baferani, 2015). The words that children utter; the actions they perform; and the attitudes they display, are all considered in the larger prism of the identities that they eventually espouse. Parents and elders will therefore approve or disapprove of such conduct in accordance with the prevailing societal norms and values.

But more players have joined the fray, with some being more impressionistic than others. Be that as it may, it does not follow that the most influential agents of character formation will necessarily be the ones advocating the right thing. On the contrary, children are increasingly taking after individuals who command public attention in matters that they can relate to - whether positively or negatively. Also known as influencers or celebrities, these individuals are setting standards in terms of dress code, lingo, diet and general social conduct. It matters less what society approves of; the individuals dictate popular culture which children take as legitimate currency. In the end, the less 
impressionistic parents and schools are left speaking a language that is alien to the children. At worst, it is a case of identity crisis, where the children are torn among parental guidance (if any), peer influence, the values taught at school, and the influence by political and social icons. The same society inspires different things, and differently so, such that it is not easy for children to decipher truths from falsehoods. It is more of the Orwellian satire in Animal Farm, wherein the difference between 'man' and 'pig' was only in the name.

\section{THE GOOD OLD DAYS}

There have been calls for restoration of ancient means of character formation. Many examples are cited as indicators of good conduct during golden days, for instance situations where children obeyed instructions from whichever elder, and more recent, when they could perform altruistic deeds such as relinquishing a seat in favour of their seniors - for instance in public service vehicles. But circumstances have changed, so that not all elders are trusted to offer appropriate instruction. Further, some charitable actions may turn illegal, for instance assisting someone to carry a luggage which is later on discovered to be either stolen property or contraband goods. Hence, we may not so much harp on what individuals regard as good, and, like Kantian ethics, wish that it be made universal. Nonetheless, there are reasons to believe that some of the traditional methods used to form character were effective, hence may be adopted if they still command relevance and acceptability. The greatest good for the greatest number, as goes Bentham's anthem, may be called to the rescue here.

In traditional setup, for example, Africans had various ways of forming good character among their offspring. Occiti (1973) and Erny (1981), for instance, report that the child's environment largely contributed to what they became in matters character. Society, for them, was a mirror in which children saw themselves, hence took after selfsame images. Generally, society took conscious and deliberate measures to nurture behaviours and dispositions it considered relatively acceptable. Nyanje (1992), for instance, reports that the Duruma of coastal Kenya resorted to killing those individuals considered grossly deviant. Others would be ostracized or even banished from their home environments, measures that served as deterrents to the would-be offenders. These practices can be seen in light of today's incarceration and capital punishment. But this was with respect to punishment as a form of character formation.

Away from punishment, other gentle means were employed, for instance teaching through oral narratives that contained moral lessons (Finnegan, 1970; Kilpatrick et al., 1992), and invoking taboos (Does the current child take such tales threats seriously?). Also, rewards were employed to encourage good behaviour, apart from direct instruction where children would be informed on the dos and don'ts relative to their societies. In as much as one may wish to adopt some of those interventions, it is not open to them to disregard the contemporary order of society. There exist issues of law and order, for instance, which dictate certain provisions that either warrant or prohibit mechanisms of dealing with vice. Man a nations have adopted the Bill of Rights which protect individuals from wilful harm in the name of punishment. Further, successive generations continue to invent their own world views, living each age according to the values they hold and cherish.

\section{Changes of Voices And Voices for CHANGE}

The current society continues to mould character among children and adults alike, albeit through not so focused means. Religious teachings are employed both in schools and outside, just as parents attempt to guide their children whenever they can. Rewards are still in place, though not as structured. But overall, punishment seem to dominate, as demonstrated by numerous rules and government laws wherein offenders - both young and old - are dealt with firmly. Expansion of prisons is such an example, an indicator that not so much is done in terms of proactive steps.

Further, the issue of integrity has found its way in the country's Constitution (RoK, 2010), under the Leadership and Integrity Chapter, underscoring the moral decadence in the society. But such laws have not deterred people of questionable integrity from occupying positions of leadership, hence cannot be relied upon to teach the young vicariously. Part of the reason is the weak link among enforcement agencies, where some lack the moral authority to call offenders to question, just as there exist those who take bribes to cover up wrongdoers. We have, for instance, several members of parliament and civil servants alleged to have forged academic certificates (Kimuge, 2021; Wangui, 2021). Arguably, it is quite difficult to demand integrity from grown-ups, especially where no concern was shown when the individuals were growing up. Accordingly, this paper holds that integrity resides in people's minds, not in rules, and that rules are beneficial only if they follow the education of the heart and mind.

Despite the notable role of the family as the first teacher in matters character formation, and that of government as a regulator of general conduct and public order, the current society seemingly presupposes that schools are major players in the inculcation of good conduct among children. Looked at objectively, there seem plausible reasons for this position. Among them is the fact that Kenyan children spend much of their time at school, only coming home for the evening and short school holidays. Further, it is relatively easier to monitor whatever values that schools impart, given the relative uniformity of learning experiences offered there. Indeed, there have been suspicions of some individuals engaging children in queer teachings outside of school, for instance radicalization, the more reason why regulated environments are preferred.

Schools, further, possess relatively well trained personnel, with knowledge of handling deviance, much more monitoring learners' behaviour. This is in contrast with some homes where parents may be clueless concerning the import and means of character formation, worse, where they act as bad models. But even those that are knowledgeable and willing to help often become hamstrung owing to the nature of their jobs. Soldiers on foreign missions, long distance drivers, and construction workers who shift from 
site to site, for instance, will not have much time with their families.

Some parents, on the flipside, deliberately ignore their responsibility, only minding their ventures, with a belief that teachers will play the role of character formators. This is illustrated by decisions to send their children to boarding school at an early age. But even more compelling is the fact that there exist children who hail from broken families, or those who have no parents at all. Foster parents and guardians may abscond their duty - either by design or default - letting children slump into moral decadence. Other children are under the custody of very old guardians/grandparents, the latter only serving to provide basic needs. In the final analysis, schools become the best bet, their reliability or lack of it notwithstanding.

\section{Why SchoOLS, SPECIFICALly?}

The issue of character formation is so important, yet so complex, raising the question as to whether schools are capable of handling it. At the bottom of it is the question of the role of schools. What are schools for? Most times, this question gets a straight answer: Education. But this is not sufficient, since one will still enquire the meaning of this 'education'. Conventionally, many scholars have defined education as a process that imparts knowledge, skills, habits and attitudes required to fit in particular societies. Plato (Ross, 2008) held that the best education was one characterized by excellence of virtue. R.S. Peters (1966), in similar fashion, regarded education as an activity which aimed at developing desirable qualities in people.

Accordingly, the aim of education is to transmit what is of value in all respects. But what are values? Who decides such values? How are they connected to education? The questions can go on ad infinitum. Granted, the foregoing definition of education allows for character formation as one of the aims of education. But the said education can be done elsewhere, for instance in homes and religious installments. Hence, there must be a major reason as to why parents sent their children to schools. Put differently, there exist certain goods which only schools offer, reason as to why children are not enrolled anywhere but in those institutions. For example, schools afford convergence of educators in different areas, all focused on achieving certain learning outcomes as a result of exposing learners to a uniform curriculum. The teaching of various academic disciplines, for instance, sets schools apart from any other social structures. Implicitly, this is the de facto focus of schooling, albeit in the narrow sense of education.

Therefore, if aspects of education were ranked, it is indubitable that the cognitive dimension would be given preference. Granted the aspect of opportunity cost, accordingly, it is not difficult to see why schools will forego all other roles in favour of the academic enterprise. But MacAllister (2011) warns that discipline, an indicator of good character, is necessary for proper learning. Hence, schools will find it easy to teach well-mannered children as opposed to problematic ones. But a problem arises when students are overly undisciplined. Then, teachers have to first bring the learners back on the rail before embarking on the task of imparting academic knowledge to them. Given the schedules at school, however, circumstances demand that the two tasks be performed concurrently, a position that leaves the teacher with the discretion of deciding the dimension that will receive more attention. Certainly, one of the aspects will suffer neglect. Be that as it may, the current paper pledges fidelity to the aspect of character formation, as much as it critiques the extent to which schools can successfully play the role.

From the foregoing, it is emerging that schools perform a teaching role. They teach various disciplines, as much as they build character. The presupposition of their teaching of character therefore prompts a revisit to the age old question as to whether character can be taught, and, may be, if schools are the best agent. Instructively, Plato (Dovre, 2007) held that character could be taught through habituation. His was in contradistinction with Socrates (in Meno), who held that virtues were not teachable in the fashion of academic disciplines, questioning the capability, hence, legitimacy of the would-be teachers (Plato, $380 \mathrm{BCE}$ ). But the fact that character is taught in schools and elsewhere (barring its success or otherwise) points to the victory of the Platonic view.

Among justifications proffered for the teaching of character include the view that individuals are born with no knowledge, hence they learn as they grow. Experience becomes the main teacher, as postulated by educational philosophers such as John Locke (Maden, 2021; Stanford, 2018) and Amos J. Comenius (Maksimović et al., 2018; Loucky, 2008). Accordingly, part of these experiences touch on character. And such character will not necessarily be good, since individuals are capable of behaving badly (and excellently so). Hence, the individuals are capable of learning good character just the way they acquired the bad one. If bad habits were acquired through bad modeling, for example, it follows that good models can equally influence good character. Further, common experience informs of individuals who have transformed from bad dispositions to good ones. Granted, the motivation behind such metamorphosis can offer valuable learning points on how to form good character.

Further argument for teaching character lies in general human views. For instance, many people will agree that certain behaviour is bad, their own conduct notwithstanding. This implies that they possess knowledge of right and wrong, the only obstruction being the commitment and will to do the right thing. As a matter of speculation, individuals who know the right way are more likely to follow it compared the ignorant ones. Accordingly, the concept of akrasia (where individuals elect to do wrong despite knowing what is right) is not reason enough to downplay character education. Indeed, there should obtain a marked difference between individuals who have been exposed to some character education and those who have had none. Bottom line, this paper argues that character can, and therefore should be taught; the only contention being the means.

\section{SchOOLS AND SOCIETY: Who IS FAILING THE OTHER?}

Many undesirable happenings, both in schools and the 
general society, continuously point to failure as far as character formation is concerned. In Kenya, for instance, there are worrying incidents of arson in schools. Students are setting their dormitories on fire, among many other instances of unrest. In the end, blame game has played out where parents point fingers at teachers, while the latter blame the former for relegating their parental responsibility of instilling discipline in their children. But parents have been quick to rebut the teachers' position, wondering why children do not burn homes, for example. Implicit in this blame game is the position that schools are continuously becoming wastelands, as Bestor (2011) would say. It is even worse for parents to blame teachers when schools seem to fail in one aspect of education, namely the affective domain, yet the same parents have been known to celebrate teachers when children pass cognitive tests. It further begs the question as to whether this narrative of blaming schools will inspire the teachers to do their, best or dampen their spirit.

As hinted at in earlier sections of this paper, many reasons militate against the teachers' responsibility in forming good character among students. Top on the list is the focus on academic activities, given that schools have a syllabus which, according to the Ministry of Education, must be covered within certain time limits. Hence, teachers focus more on class work, leaving little or no time for other aspects. Indeed, national tests only provide for the cognitive domain of education, where a learner's excellence is measured solely by their intellectual capacity. For instance, learners who perform dismally in their academic disciplines are declared failures pronto, never mind their excellence in good character.

But other challenges equally stand in the way of teachers, as much as they would wish to inculcate certain values among the learners. Their training, for instance, is in supposition. Teacher educators focus more on subject content and pedagogical skills, leaving little space for handling the issue of character formation. It is worth noting that even the guidance and counseling units in most schools are manned by teachers deficient in relevant knowledge and skills (Warui, 2018; Boitt, 2015). At best, those teachers with training in humanities, for instance religion and social studies, are often picked to champion character formation. The rest of teachers do not view it their official duty to inculcate good character among learners, with unruly children being referred to either the teacher on duty, the class teacher or the deputy head teacher (often in charge of discipline issues). This lack of collective responsibility has for long been an impediment to character formation in schools.

Another challenge emanates from teachers themselves, wherein they fail in their role as good models. Modeling remains the best way to form character (Lickona, 2008; Mullins, 2005). The power of the teacher can never been fathomed beyond their own character. For learners, it has always been a case of 'monkey see monkey do', hence teachers ought to be wary of what they say and do, and how they do whatever they do, for all these serve powerful communication to the learners (Lickona, 2001). There is a reason, for instance, why teachers should dress modestly. The manner in which they address learners, and attend to disputes, equally provide lessons to students. Further, those acts that teacher consider trivial, for example late attendance to classes, only serve to downplay the importance of punctuality. Teachers who often arrive late, whether in school or classroom, are well known to learners unfortunately for bad reasons. Moreover, lack of democratic practices dehumanize learners, making them fail to recognize the need for fairness, consultation, accountability, transparency and mutual respect. A teacher who fails to listen to learners' grievances is no different from their tormentor. Similarly, treating learners condescendingly teaches them to be callous. Good teacher-learner relationship boosts the dialogical dimension, hence opening the learners' hearts that are at the centre of developing good character (Devine et al., 2000). The heart opens way to the mind: when a student cannot feel the teacher, they just cannot learn from him/her.

But again, there is this small matter of 'discipline', and what it means as far as the school context is concerned. For many parents, schools exist to 'discipline' learners. The term connotes many things, including punishment and orderliness. So, schools set rules, and children who obey them to the letter are termed disciplined. It is more of managing learners' behaviour (MacAllister, 2011), much less submission to rules, a position that begs the question as to whether such means can achieve character formation among learners.

But one may argue that obedience to rules is one of the stages towards formation of conscience, and, as such, an individual with a well-developed conscience is able to differentiate right from wrong - with proclivity towards righteousness. Granted, it is safe to assert that obedience to rules, if sustained, may, in a way, contribute towards character formation - but not exclusively. Even so, it is worth distinguishing between obedience and obeisance; the former follows certain conviction, while the latter results from coercion. Such being the case, the school system ought to be designed in a manner that naturally and humanely encourages good behaviour as opposed to the use of unreasonable force. Learners ought to understand the essence of good character, a position that will give them impetus to behave well without necessarily being followed up. This is to say that the methods employed to form character ought to be ones that are not only intelligible, but those that are human - as Freire (1970) advocated. Knowledge and conviction are the precursor to moral action.

The foregoing position serves to elucidate the point that teachers ought to be made aware of how their attitude towards the nature of learners, and their consequent treatment of the latter, affects character formation. If learners are perceived as savages, and schools as saviours (Peters, 1966), then all means - mostly crude - will be employed to 'beat the hell' out of these supposed barbarians. Further, any deed or word, coming from the learner will be viewed as negative by default until proved otherwise. It will not be surprising, therefore, when a courageous learner, for instance, is viewed as arrogant. The same will apply to the learner's creativity wherein the actor will be viewed as a troublesome. A commonplace example is the case where we spent time and money encouraging toddlers to speak and walk, only to turn around later and spent even more time imploring them to sit down and remain silent! So schools, 
being convergent points for learners of all kinds, may need to be extra-vigilant and cautious in the manner in which they approach formation of character. The issue of peer pressure, arising from group dynamics, has great bearing in the way the learners ultimately become as far as character goes.

Additionally, peers form another strong set of educators. For one, they speak the same 'language', and two, they are at the same level in terms of power hierarchy, unlike their teachers who present an imbalance of power. Granted, these learners can teach each other whatever they deem valuable to themselves and do so with unrivalled effectiveness. This explains why teachers ought to be proactive lest the learners pick wrong lessons from one another. Aristotle, in his Moral Virtue Theory (Ross, 1908) advanced that all persons are born with the potential to acquire virtue. Therefore schools, being environments that presuppose deliberate learning, should capitalize on their position and teach all the right things that they can. Reasoned checks and balances have to be instituted, as it were, if the learners are to become anything close to what society desires.

Whereas teachers have had their fair share of blame, it is instructive that some factors, beyond their control, have militated against effective character formation. The most compelling one is plurality of values. To form character, one must emphasize certain values. Tragedy is that some of the values taught at school are at variance with what learners know from their communities. At times, it boils down to socio-cultural dispositions. Whatever a particular community regards as a value, for instance, may be a weakness in the other. Such a situation narrows down to the school level, and can be manifest in form of juvenile feuds. For instance, Christians forbid revenge. If a Christian student is assaulted by another, for example, the victim need not hit back but report - and later forgive the assailant. This, however, may be misconstrued for cowardice in cases where students hail from warring communities, or those whose families constantly engage in scuffles.

But the foregoing is subtler, compared to cases where the general society portrays dalliance for vices such as theft and insults. In Kenya, each passing day sees news of politicians hurling epithets at each other on national television; individuals accused of stealing public funds; and influential figures, such as top artistes, engaging in wayward behaviour. It therefore becomes difficult for teachers to discourage such vices, given that the perpetrators are notable personalities who, according to society, lead successful lives. By virtue of their apparent success, mostly at the economic level, these individuals are viewed as heroes, hence all their actions viewed as heroic. Members of parliament engage in individual fights publicly, and so is the clergy who have had part of their lot making news for all the bad reasons. In the end, the learner becomes confused, unable to choose whom to believe. But considering that the larger society is more impressionistic, teachers' views are largely disregarded in favour of the most compelling, concrete ones from the outer society. All these notwithstanding, it still remains a task for schools to find ways of convincing learners that the right way is the only way, and that good character will ultimately make each one's live more bearable and worth living.

\section{CONCLUSION}

Listening to all the negative stories in society paints a bleak picture. However, this needs not be the case; all is not lost. Schools still command certain powers as pertains character formation. We have teachers who live exemplary lives, hence influence their learners positively. Others have led learners in discussing and clarifying moral issues, effectively creating understanding and ultimate decisionmaking among the students. Further, most teachers are known to hold high expectations from students, not to mention the various reward systems put in place - however menial - for those who conduct themselves appropriately. Albeit piecemeal, such steps generally contribute to the apparent harmony observed in most learning institutions. It probably explains why the society has not exploded into complete anarchy and immorality despite the bad influence from a few individuals. Schools should therefore continue doing their best as far as character formation is concerned, despite the prevailing perception of failure. Teachers ought to re-invent ways of forming good character, over and above mere information about character. Further, character education programmes should be tailored such that they appeal to the learner's reason, a move that will create conviction towards doing right. This must be made possible since, at least for now, schools are all we have as far as structured character formation is concerned. All in all, more targeted researches ought to be conducted with a motive of establishing better ways of forming good character among the current generation, given that most traditional modes seem unappealing to the youngsters, much more, societal values are changing in response to current social, economic, technological spaces.

\section{CONFLICT OF INTEREST}

Authors declare that they do not have any conflict of interest.

\section{REFERENCES}

Baferani, M. H. (2015). The role of the family in the socialization of children. Mediterranean Journal of Social Sciences, 6(6S6), 417. https://www.richtmann.org/journal/index.php/ mjss/article/view/8516. DOI:10.5901/mjss.2015.v6n6s6p417.

Bestor, A. E. (2011). Educational wastelands: The retreat from learning in our public schools. Montana: Literary Licensing, LLC.

Boiit, M. L. J. (2016). Evaluation of the challenges in the implementation of the guidance and counselling programme in Baringo county secondary

Kenya. Journal of Education and Practice, 7(30), 27-34. https://files.eric.ed.gov/fulltext/EJ1118929.pdf

Devine, T., Seuk, H. J., Wilson, A. (2000). Cultivating heart and character: Educating for life's most essential roles. Chapel Hill, NC: Character Development Foundation.

Dovre, P.J. (2007). From Aristotle to Angelou: Best Practices in Character $\begin{array}{llll}\text { Education. } \quad \text { Education Next, } & 7(2) 38-45 .\end{array}$ http://www.google.com/m?q=Dovre+on+character+education\&client $=\mathrm{ms}$.

Erny, Pierre (1981). The Child and his environment in black Africa. Nairobi. Oxford University Press.

Finnegan, R. (1970). Oral Literature in Africa. Nairobi. Oxford University Press.

Freire, P (1970). Pedagogy of the oppressed. England: Penguin Publishers.

Kilpatric, W., Wolfe, G., Wolfe, M.S. (1992) Books that build character: A guide to teaching a child moral values through stories. New York: Simon and Schuster. 
Kimuge, S. (2021, June 3). 250,000 civil servants face the axe over fake academic papers. Daily Nation. https://nation.africa/Kenya/news/250-000-civil-servants-face-the-axeover-fake-academic-papers-3423612.

Knapp, P. (1994). One world - many worlds: Contemporary sociological theory. New York: Harper-Collins.

Lickona, T. (1991). Educating for character: How our schools can teach respect and responsibility. New York: Bantam Books.

Lickona, T. (2008). The power of modeling in children's character development. In D. Streight (Ed.),

Parenting for character: five experts, five practices. Centre for spiritu al and ethical education. https://www2.cortland.edu/dotAsset/194017.pdf.

Loucky, J.P. (2008). Reassessing the educational works and contributions of Comenius to the development of modern education. https://core.ac.uk/download/pdf/233568828.pdf.

MacAllister, J. (2011). Wisdom and the life of virtue: What should discipline be for in schools? [Unpublished Doctoral dissertation]. The University University of
http://www.era.lib.ed.ac.uk/handle/1842/5841.htm.

Maden, J. (2021). John Locke's empiricism: Why we are all tabula rasas (blank slate). https://philosophybreak.com/articles/johnlockes-empiricism-why-we-are-all-tabula-rasas-blank-slates/.

Maksimović, J. ., Osmanović, J., Milanović, A. (2018). John Amos Comenius contribution to the development of the didactic methodology.

https://comenius.uph.edu.pl/images/pliki/seria_pedagogika_5/artykuly /tom_v_artykul_6.pdf

Mullins, A. (2005). Parenting for character. Lane cove, Australia: Finch Press.

Nyanje, B. D. (1992). The basis of moral values: A case study of the Duruma of Kenya'. [Unpublished MA Thesis]. Kenyatta University.

Parsons, T. (1951). The social system. New York: Free Press.

Peters, R.S. (1966). Ethics and education. London: Allen and Union.

Plato (380 BCE). Meno. Trans. Benjamin Jowett. http://classics. mit.edu/Plato/meno.html.

Ocitti, J. P. (1973). African indigenous education as practised by the Acholi of Uganda. Nairobi: Kenya Literature Bureau.

RoK (2010). The Constitution of Kenya. Nairobi: Government Printer.

Stanford (2018, October 21). John Locke. https://plato.stanford.edu/entries/locke/

Wangui, J. (2021, May 25). MP Oscar Sudi loses bid to block fake certificate case. Daily Nation.

https://nation.africa/kenya/news/mp-oscar-sudi-loses-bid-to-blockfake-certificates-case--3413668.

Warui, J. W. (2018). Status and challenges of guidance and counselling programme in discipline management in public secondary schools in Kiambu County, Kenya. [Unpublished Thesis]. Kenyatta University.

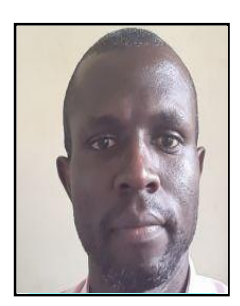

Wycliffe Osabwa is a PhD student in the

Department of Educational Foundations, School of Education, Kenyatta University - Narobi, Kenya. He is also a Tutor at Alupe University College - Busia, Kenya, where he teaches courses in educational foundations. He specializes in Philosophy of education, and has interest in educational research (theory and praxis) as well as qualitative research methods.

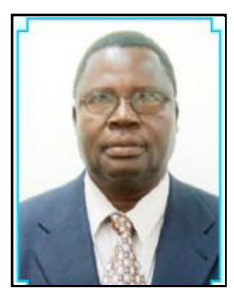

Dr. Jackton Ogeno lectures in the Department of Educational Foundations, School of Education, Kenyatta University, Nairobi, Kenya. He previously served as Dean of the School, and has several publications, conference presentations and various other major feats in the arena of education. He specializes in Philosophy of Education, in as much as he teaches other courses that fall under foundations of education.

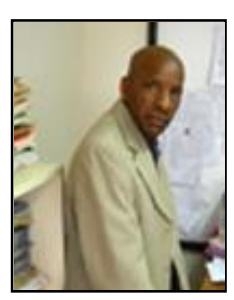

Dr. Daniel Batso Nyanje lectures in the department of Educational Foundations, School of Education, Kenyatta University - Nairobi, Kenya. He specializes in Philosophy of Education, as much as he teaches educational foundations courses. He has held various positions in the Department and chaired various committees within the School. He has several conference presentations and publications. 